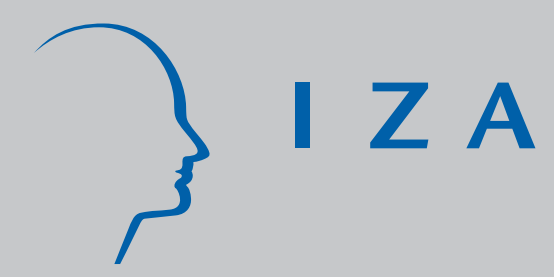

IZA DP No. 1715

Immigrant Performance and

Selective Immigration Policy:

A European Perspective

Amelie Constant

Klaus F. Zimmermann

August 2005 


\title{
Immigrant Performance and Selective Immigration Policy: A European Perspective
}

\author{
Amelie Constant \\ IZA Bonn \\ Klaus F. Zimmermann \\ University of Bonn, IZA Bonn \\ and DIW Berlin
}

\section{Discussion Paper No. 1715 \\ August 2005}

\author{
IZA \\ P.O. Box 7240 \\ 53072 Bonn \\ Germany \\ Phone: +49-228-3894-0 \\ Fax: +49-228-3894-180 \\ Email: iza@iza.org
}

\begin{abstract}
Any opinions expressed here are those of the author(s) and not those of the institute. Research disseminated by IZA may include views on policy, but the institute itself takes no institutional policy positions.
\end{abstract}

The Institute for the Study of Labor (IZA) in Bonn is a local and virtual international research center and a place of communication between science, politics and business. IZA is an independent nonprofit company supported by Deutsche Post World Net. The center is associated with the University of Bonn and offers a stimulating research environment through its research networks, research support, and visitors and doctoral programs. IZA engages in (i) original and internationally competitive research in all fields of labor economics, (ii) development of policy concepts, and (iii) dissemination of research results and concepts to the interested public.

IZA Discussion Papers often represent preliminary work and are circulated to encourage discussion. Citation of such a paper should account for its provisional character. A revised version may be available directly from the author. 


\section{ABSTRACT \\ Immigrant Performance and Selective Immigration Policy: A European Perspective*}

The European Union aims at a stronger participation by its population in work to foster growth and welfare. There are concerns about the attachment of immigrants to the labour force, and discussions about the necessary policy responses. Integrated labour and migration policies are needed. The employment chances of the low-skilled are limited. Whereas Europe could benefit from a substantive immigration policy that imposes selection criteria that are more in line with economic needs, the substantial immigration into the European Union follows largely non-economic motives. This paper discusses the economic rationale of a selective immigration policy and provides empirical evidence about the adverse effects of current selection mechanisms.

JEL Classification: F22, J15, J31, J61, J68, J82

Keywords: migration policy, ethnicity, migrant workers, asylum seekers, family reunification

Corresponding author:

Klaus F. Zimmermann

IZA

P.O. Box 7240

D-53072 Bonn

Germany

Email: zimmermann@iza.org

\footnotetext{
* Financial support from Volkswagen Foundation for the IZA project on "The Economics and Persistence of Migrant Ethnicity" is gratefully acknowledged. We wish to thank the Rockwool Foundation Research Unit, especially Claus Larsen, Marie Louise Schultz-Nielsen, Niels-Kenneth Nielsen and Torben Tranaes, and Statistics Denmark in Copenhagen for valuable help with the Danish part of the data set used in this study during research visits in May and June 2005. We also thank John Ermisch and a referee for helpful comments on an earlier draft.
} 


\section{Introduction}

The growth perspectives of European Union member countries are seen to be crucially related to the challenge of mobilising people to work. One issue is that non-economic migrants have more difficulties in economic performance and labour market integration, and provide a larger potential burden to the social security systems than economic migrants. Recent work on Denmark and Germany (see Tranaes and Zimmermann, 2004a, and especially Schultz-Nielsen and Constant, 2004) has provided new evidence, and found that an ever rising share of immigrants is unavailable to the labour force. Instead, migrants arrive as refugees, asylum seekers or for family reunification purposes. Differences in labour market attachment might be due to differences in individual characteristics across ethnicities, or they can be associated with their legal status at entry.

Another European challenge of increasing importance is the rising deficit of high-skilled workers. This is a matter of size and intensity. Even in the long-term, it will be difficult for European firms to hire the appropriate quantities on their local labour markets. Supply is not likely to keep pace with demand. A permanent effort will be needed to participate in the rising world market for flexible high-skilled workers. This international effort is a prerequisite for keeping the own talents and the hired migrants of the European Union member countries. Appropriate policy instruments have to be found to enable companies to deal with this challenge.

Responses to these crucial challenges require evidence on the economic mechanisms of migrant selection and informed policy analyses about potential selection strategies. This could provide guidance for an integrated labour and immigration policy. A recent Green Paper by the Commission of the European Communities (2005) has recognised these challenges and puts concerns about admission procedures for the economic immigration of non-EU nationals in the forefront of their policy discussion. It has created a reform discussion and announced a policy plan on legal migration including flexible admission procedures by the end of 2005.

Our paper contributes to this policy debate. Its novel feature is that we aim to 
understandthe role of the legal status of the migrant at the time of entry in the host country (work permit, refugee, and kinship) on work participation and earnings. We also investigate actual migration policy mechanisms reflecting explicit or implicit policy decisions and the related characteristics among the immigrants within the different channels of entry. Our research suggests that, even after controlling for skill-level, non-economic migrants are less active in the labour market and exhibit lower earnings.

The paper is organised as follows: Section 2 summarizes the economic framework for migration analysis and the empirical evidence for Europe, and analyses the policy stands of the European Union concerning migration and the vitalisation of the workforce. Section 3 presents new econometric evidence using fresh and unique survey data on immigrants from Germany and Denmark to study the determinants and economic effects of their legal status at entry. Section 4 summarises and derives policy conclusions.

\section{Labour Migration: Theory, Empirics and Policy Lessons}

\subsection{The Economic Framework}

Economic theories concerning migration seen from the host country perspective can be organised around three major themes (Zimmermann, 1995, 2005 and Venturini, 2004): (i) the determinants of migration, (ii) the assimilation of the migrants, and (iii) the effects of the immigrants on the natives. Labour migration decisions respond largely to differences in regional disparities in prosperity. Hence, differences in earnings, unemployment rates, cost of living, public goods and public transfers are important determinants of a move. The decision to move is also affected by the costs of moving that not only include monetary costs like travel expenses, and foregone earnings during the move, but also psychological costs arising from the separation from family and friends. According to the human capital model, the likelihood of migration decreases with age, reflecting the smaller expected lifetime gain from moving for older people. Individuals with higher education should exhibit a higher migration probability, because higher 
education reduces the risks of migration through a higher ability to collect and process information. The risks and costs of movements are expected to rise with distance, because information about labour market conditions is expected to be better for closer locations. Family ties also typically play an important role. Most migrants move within the context of ethnic networks, resulting in the formation of ethnic clusters in the host country. The mere existence of network and chain migration significantly alleviates the risks and costs, and accelerates movement.

How do the migrants fare? This is the question of assimilation and integration into the labour market of the host country (see for example Boeri, Hansen and McCormick, 2002, and Bauer, Lofstroem and Zimmermann, 2000). According to the standard economic models in this field, the degree of assimilation is influenced by individual factors, the characteristics of the home and host countries, the migration motive, and the expected migration duration. The greater the similarity between the sending and the receiving countries in relation to their economic development, the more rapid is the assimilation. Individuals who migrate for economic reasons, permanent migrants and those with good knowledge of the language of the host country are expected to integrate and assimilate faster than non-economic and temporary migrants.

A key issue is the international transferability of human capital. Human capital acquired at home may not be fully transferable to the host county. Hence, it is expected that the lower the international transferability of human capital, the higher is the earnings disadvantage of the migrants at the time of migration. With increasing time of residence in the host country, immigrants invest in country-specific human capital of the receiving country and adapt their stock of human capital acquired in the home country. As a consequence, the human capital of the immigrants grows relatively faster than the human capital of the natives, and the earnings of the immigrants approach, but may not always reach, those of the natives.

An important issue is how the natives are affected by the immigrants (see Borjas, 1994, and Bauer and Zimmermann, 1997). The evaluation crucially depends on the conditions on the 
labour markets of the host country. These markets might be either competitive or in disequilibrium; that is labour supply equals labour demand or not, respectively. A further decisive aspect is that the labour force in the host country is likly to be heterogeneous and of diverse quality; then the immigration impact depends on whether immigrants are unskilled or skilled. Disequilibrium situations in labour markets may occur when there are institutional constraints in the market for unskilled labour such as union wages, minimum wages or transfers like social assistance, or when the educational system is not able to provide the necessary supply of workers for the skilled labour markets. Another issue is whether skilled and unskilled workers are complements or substitutes to natives. A reasonable (and standard) assumption is that skilled and unskilled workers are complements, which implies that one group becomes more productive (and relatively scarce) when the input of the other group is increased.

If there is unemployment among low-skilled workers due to institutional constraints like union wages, the entry of unskilled migrants willing to work outside the union sector will make the labour market more competitive and also create additional jobs for the natives through reduced wages. If immigrants are predominantly unskilled, then they are substitutes for unskilled natives and complements to skilled natives. Accordingly, new immigrants may depress wages and increase unemployment among unskilled native workers and may have the reverse effects for skilled natives. The reverse scenario will occur with skilled immigration. Hence, in a situation of unskilled unemployment and excess demand for skilled work, it makes sense to encourage the entry of high-skilled labour migrants.

Institutional constraints on labour markets, high unemployment among the low-skilled and excess demand for the skilled workers broadly describes the predominant situation in the European Union, currently and in the longer-term future. A selective immigration policy that tends to avoid unskilled migrants and attract skilled foreign workers would, therefore, be a safe strategy to foster growth, increase demand for unskilled native workers, and be beneficial for all. For these reasons, migrants can be 'good economic friends' to natives in the labour market. 
The policy challenge is to optimize migration to increase welfare by identifying and mobilising the economic component of the process. In a long-term steady-state where immigrants are fully assimilated in the sense that they are like the natives, with similar human and physical capital, there is no real advantage, but also no disadvantage for the host nation. According to standard economic models, the production possibilities are then just shifting outwards with no effects on the income distribution and the welfare levels. However, when migrants are different but in demand, when they bring variety into the labour force, and when they improve the speed of the adjustment of the host economy to its long-run needs, they are of invaluable help.

\subsection{Empirical Evidence: Assimilation and Impacts on the Natives}

A large number of studies in the economic literature (see Zimmermann, 2005, and Tranaes and Zimmermann, 2004a, for rich overviews of European evidence) have investigated the empirical answers to the key economic questions of immigration: Are migrants taking jobs away and depressing the wages of the natives, or do they contribute to the creation of jobs and increase the general level of wages? Do they adjust to the host country's labour market, in the sense that they work and perform as well as natives or even better than natives in the labour market? Are they just a burden on the welfare state or do they impart economic gains through increased productivity and higher tax revenues and social security payments?

The Nordic welfare states, especially Denmark and Sweden, do not receive many typical non-EU labour migrants. These states probably have attracted fewer workers due to the absence of explicit hiring policies, a limited national labour market and the fact that economically motivated migration flows follow ethnic networks. Hence, migrants who come to Europe are more likely to move to countries like Germany and Austria. In recent years, the number of nonEuropean migrants has increased mainly due to the immigration of relatives and refugees. First generation migrants have not fared well in comparison to natives, but second generation 
migrants are becoming more similar to the natives. The relative success of second generation migrants can be traced to parental capital and to neighbourhood effects which operate through higher educational levels. Immigrants and refugees tend to concentrate in a few neighbourhoods in the bigger towns or cities with subsequent political tensions and social frictions.

Ireland and Great Britain share a common migration experience through the large Irish emigration to the British mainland. Ireland has traditionally been an emigration country, while the United Kingdom has largely restricted immigration to people from its former colonies. Recently, and associated with the rising success of its economy, Ireland seems to have benefited from the inflow of skilled people who have made an important contribution to the economy and assisted in reducing earnings inequality. While British migration is largely driven by economic incentives, the free flow of labour has been distorted by growing policy intervention. As a consequence, migration policy has become inextricably linked with domestic race relations policy. The ethnic minority population exhibits rising educational levels, especially in the second and subsequent generations. Labour market disadvantages seem not to be caused by discrimination but by a slow assimilation process, whereby immigrants can only improve their labour market status with length of residence.

Central Europe encompasses the traditionally attractive labour markets of Germany, Switzerland, Austria, the Benelux countries, and France. France has gone through similar phases of de-colonization and labour hiring as the Netherlands. French immigration policy has focused on people who were willing to accept the French language and culture. However, the majority of the immigrant population in France is manual workers and suffers from poor labour market conditions. The Dutch ethnic minorities are also in a disadvantaged socio-economic position. Cultural aspects, less functional social networks and human capital factors are likely culprits of the immigrants' plight or marginalization. While second-generation migrants are making progress, they are not fully integrated economically or socially. 
The most important European immigration country is Germany, which similar to the Netherlands, has been traditionally the port for many labour migrants. Germany, however, has also attracted substantial inflows of non-economic migrants such as relatives of inhabitants, refugees, and ethnic Germans from Eastern Europe. Ethnic Germans are generally found to assimilate, although at a slow rate. This has become more problematic with their recent immigration waves. Foreigners today are under more labour market pressures than natives. This is largely the consequence of occupational status, and not of behaviour. Self-employment is a channel for integration into the economy (see Constant and Zimmermann, 2005). There is no empirical indication that migrants depress native wages or increase their unemployment risk. Immigration effects are either small or insignificant, or they have a positive impact on the economic situation of the natives (see Bauer, Dietz, Zimmermann and Zwintz, 2005).

For decades, the southern European countries like Italy, Greece, Spain, and Portugal experienced net outmigration. They are now in a process of becoming countries of immigration, receiving people from Northern Africa, the Balkans, emerging economies, and other less developed parts of the world, mostly through illegal immigration. The available Italian research on the impact of foreign workers on the natives has provided only a few cases of negative findings. There is even some evidence of complementarity between migrants and natives, suggesting that immigration may actually improve the labour market conditions of the natives. If the effects of the immigrants on the labour market are shown to be negative, like in the illegal sector, the estimated effects are small and of negligible economic importance. An exception is the illegal part in the agricultural sector where natives and migrants are strongly competitive. Illegal immigrants in Greece are mostly in agriculture, but also in construction and service industries. Empirical studies show that foreign workers in agriculture largely took available vacancies and even generated their own jobs. Immigration did not raise the overall unemployment of natives, and in some selected industries such as in construction and services there were some negative effects. Migration in Spain has become more domestic, with a strong 
rise in intra-regional migration. This increase in migration is a response to rising employment opportunities in the service sector in all Spanish regions. Although foreign immigration is still low in Spain, as it is in Portugal, its size is growing strongly and it is rapidly gaining attention.

The lessons one can draw from the European experience are twofold: In the past, the labour market integration of migrants has been slow, but steady. The impact on the natives has not been very strong, but mostly beneficial. However, with globalisation, the particular pressure on low-skilled workers, and the increased demand for high-skilled people, the nature of the game appears to be changing. The economic position of the new immigrants has become weaker. From this perspective, a selective immigration policy appears to be even more important than before.

\subsection{Migration Policies: From the Lisbon Agenda to the EU Green Paper}

In response to various concerns about the economic prospects of the European Union, the European Community has been implementing various political strategies (see Sapir Report 2004). Among the recent initiatives have been the Lisbon Agenda, which aims at making Europe by 2010 the most competitive and dynamic knowledge-based economy in the world, capable of sustainable economic growth, with more and better jobs and greater social cohesion. The Lisbon Agenda states that employment and economic policies should aim at a rise of the overall employment rate in Europe. The Lisbon targets call for employment rates as close as possible to $70 \%$ of the population aged 15-64, and an increase in the employment rate for women to more than $60 \%$. In order to achieve these goals, the labour market implications of immigration have to be taken into account.

In June 2003, the European Commission adopted a "Communication on Immigration, Integration, and Employment" that studied immigration in the context of demographic change and proposed a strategy to promote the better integration of immigrants and to prepare for attracting more immigrants in the medium-term future. The need for such initiatives is suggested by the fact that, even if the Lisbon targets are achieved by 2010, employment in Europe will 
subsequently fall significantly due to population aging (see Lisiankova and Wright, this volume). Achieving sustained economic growth would require a greater increase in productivity than what can probably be achieved. It is, therefore, important to mobilize the current stock of migrants about to enter the labour market, and to prepare for new immigration by implementing better entry measure and integration strategies.

The employment rates for 2002 (see European Communities, 2003) suggest that the European Union is still far from reaching these goals. Increases of about 6 percentage points for the total EU employment rate (from 64.3\% in 2002) and about 4 percentage points for the female EU employment rate (from 55.6\%) have to be materialized to ensure that the targets are achieved. EU-national immigrants exhibit overall high employment rates (66.4\% in total and $58.8 \%$ for females), and are hence closer to the employment goals. This also suggests that their mobility is driven largely by the desire to work. However, non-EU immigrants have exceedingly low employment rates. Unlike EU nationals, they are not well integrated into the labour markets. Employment rates are around 50\% for the total non-EU immigrant population, and around $40 \%$ for non- EU females. There is a substantial integration problem with respect to non-EU nationals in the European labour markets. Another marginalized group in Europe is the low-skilled, including both foreigners and natives; their total employment rate in the EU is only 49\%. Lowskilled natives and non-EU migrants compete for jobs. The mirror picture is provided by the unemployment statistics. EU national migrants exhibit a rate of $7.1 \%$, which is marginally below the $7.7 \%$ for the EU in total. Non-EU migrants have a high unemployment rate of $15.8 \%$, which is much higher than the $10.8 \%$ of the European unskilled.

This leads to three important issues: First, the success of the Lisbon Agenda will depend mainly on the ability to provide jobs for the low-skilled. (The employment rates of the mediumskilled (70.5\%) and the high-skilled (82.8\%) already fulfill the $70 \%$ rule.) It will also help to encourage more females into work, but the deficits with respect to the Lisbon goals are much smaller for females than for the low-skilled. Second, non-EU migrants are largely 
underemployed. This integration problem is not only socially unsustainable, but it is also economically irrational. If more is done to attract the low-skilled population in general to enter employment, this may also help the non-EU national migrants since they are largely low-skilled. However, an even more active integration policy with early training measures is desirable to attract non-EU nationals into work. Third, in the face of the current and probably rising deficits in skilled workers in the medium term, a selective immigration policy could help to reduce the inflow of low-skilled people and to obtain a credible position in the international labour markets for high-skilled and well-trained workers.

A newly prepared Green Paper by the Commission of the European Communities (2005) has recognised these challenges and puts concerns on admission procedures for the economic immigration of non-EU nationals in the forefront (p. 4): "More sustained immigration flows could increasingly be required to meet the needs of the EU labour market and ensure Europe's prosperity. Furthermore, immigration has an increasing impact on entrepreneurship. The EU must also take account of the fact that the main world regions are already competing to attract migrants to meet the needs of their economies. This highlights the importance of ensuring that an EU economic migration policy delivers a secure legal status and a guaranteed set of rights to assist the integration of those who are admitted."

The Green Paper also suggests that it is now time to engage on a new round of discussions to develop a stronger basis for a European migration policy that takes into account the employment goals of the Lisbon agreement and the long-term implications of the upcoming demographic changes. It urges European Union member states to agree on "transparent and more harmonized common rules and criteria at EU level for admitting economic migrants” (p. 4). It discusses admission procedures for both conventionally paid-employment and self-employment. And it stresses the idea that a successful migration policy can only be achieved through collaboration among the European Union member states, the countries of origin and the transit countries. 


\section{Migrant Selection and Economic Performance: The German-Danish Case}

In this section, we investigate the German and Danish immigrant situation. This analysis will provide evidence on two important findings that are of general importance for the European Union in general: (i) There are few migrants who arrive through the channel of an explicit work permit, and even those are not strongly selected to meet the needs of the labour markets. (ii) Those not selected through the economic channel are significantly less integrated into the labour market and they earn less than their countrymen.

The broad picture of the migration evidence on Denmark is contained in Petersen (2005) and on Germany in Bauer, Dietz, Zimmermann and Zwintz (2005). The first elaborate international comparative study examining the immigration experiences in Germany and Denmark is by Tranaes and Zimmermann (2004a, see especially the chapters by Constant and Schultz-Nielsen, 2004a and 2004b). Here we use the survey data sets investigated by Tranaes and Zimmermann (2004a) to provide new evidence on the determinants of legal status of entry of immigrants and the impacts of the channels chosen on work participation and earnings.

\subsection{Data and Modeling Device}

In order to study empirically the labour market position and earnings of immigrants we use data from the Rockwool Foundation Migration Survey - Germany (RFMS-G) and Rockwool Foundation Migration Survey - Denmark (RFMS-D). For a more elaborate introduction into the data sets see Tranaes and Zimmermann (2004a), especially Tranaes and Zimmermann (2004b) and Bauer and Niels-Kenneth Nielsen (2004). Conducted by Infratest Sozialforschung in Munich and Statistics Denmark in Copenhagen these surveys are based on similar questionnaires and administered to the same ethnic groups in Germany in 2002 and Denmark in 2001. The German survey includes 5,569 immigrants from ex-Yugoslavia, Poland, Iran, Lebanon, and Turkey, who represent about $66 \%$ of the immigrant non-Western population in Germany. The Danish survey, 
which is representative for Denmark, includes 3,262 immigrants from the five aforementioned countries as well as immigrants from Somalia, Vietnam, and Pakistan, who we will not use in this comparative study. Unlike the German data set, the Danish data combines survey information with information from the registers of Statistics Denmark.

For compatibility and comparison purposes, our selected sample includes only the same five immigrant nationalities in both countries. The selected samples for the analysis include individuals aged 18 to 65, who are not students, or in training/apprenticeship. We also exclude military personnel and those in early retirement, or those who rule out regular work. Further, the purpose of this paper is to investigate the performance of immigrants who arrive through three specific channels: the asylum or refugee channel, the family reunion channel and the employment channel. We, therefore, exclude children of immigrants born in Germany or Denmark, and those migrating as children, who had no choice in the migration decision. According to these selection criteria, the German sample is reduced to 3,845 observations and the Danish sample to 1,415 observations.

Empirically, we estimate a multinomial logit model for the probabilities of arriving through kinship, the asylum or refugee channel and the employment channel, respectively. The latter is the reference category. In this exercise the independent variables are characteristics that are given upon arrival and do not change with time in the host country. Next, we estimate a Tobit model for earnings, and we control for the status at entry. Here, we emphasise differences in paid- and self-employment.

\subsection{Empirical Findings}

In the German sample, the majority of the immigrants arrived through the family reunion channel (1,647 people or $42.8 \%)$. The next largest channel of immigration is asylum seekers or refugees (1,572 people or $40.9 \%)$. Economic migrants are only 626 or $16.3 \%$. A similar distribution, albeit more pronounced, holds in the Danish sample: 682 people or $48.2 \%$ arrived 
through kinship, 652 people or $46.1 \%$ arrived through the asylum or refugee channel, and only 81 people or $5.7 \%$ arrived as economic migrants. In the German sample 202 observations are self-employed or $10.1 \%$ of the working sample (and $5.3 \%$ of the entire sample), and in the Danish sample 122 observations are self-employed or $13.0 \%$ of the working sample (and $8.6 \%$ of the entire sample).

Figure 1 illustrates the relationship between employment rates and gross weekly earnings by ethnicity for both countries. Specifically, we plot this relationship for all five ethnic groups of immigrants for Germany and Denmark. Although we find an expected positive relationship between employment and earnings, this figure clearly shows major differences among the immigrant groups and between the two countries. Figure 1 separates into two parts. All five immigrant groups in Germany earn less than their ethnic counterparts in Denmark. Immigrants in Denmark also have higher employment rates than their countrymen in Germany. In both countries, Poles rank the highest and Lebanese rank the lowest with respect to their employment proportion, while Turks, Iranians and the Lebanese represent a middle group.

Figure 1 about here

In Figure 2 we juxtapose the five immigrant groups in Germany and Denmark and show the relationship between self-employment rates and the ratio of self- over paid-employment gross weekly average earnings. With the exception of the ex-Yugoslavs in Denmark, Figure 2 shows that all self-employed immigrants in Germany earn a higher premium for selfemployment than their self-employed countrymen in Denmark. However, the self-employment rate for each ethnic group (with the exception of the Danish ex-Yugoslavs) is higher in Denmark than in Germany. Immigrants in Denmark earn a smaller self-employment premium, although their self-employment rates are higher than immigrants in Germany. There must be other motives than income or ethnic entrepreneurship that push migrants into the self-employment category, perhaps the absence of employment possibilities. However, within each country, there is no clear-cut relationship between self-employment rates and relative earnings. 
Figure 2 about here

The objective of our first econometric analysis is to identify the characteristics of migrants in each of three channels of entry, namely (i) work permit, (ii) kinship and (iii) refugee and asylum seeker status. It also allows us to explore how each channel responds to labour market skills such as education. Table 1 presents multinomial logit estimates of the effective immigrant selection functions associated with the migration policies of Germany and Denmark. Using the economic status (i) as the reference category, this table decomposes the two other channels according to observable characteristics such as age at entry, education and work experience in the home country, gender (male), father self-employed, Muslim faith, church attendance, help through an immigration network before arrival, and ethnicity (ex-Yugoslavs, Poles, Iranians, and Lebanese, leaving Turks as the reference group). Table 1 contains the parameter estimates and the respective marginal effects. Note that the sign and significance level of the parameters can differ between parameter estimates and marginal effects since the calculation of the marginals involves the parameter estimates of all alternative states. In the sequel we will base our summary on the reported marginal effects. Robust t-ratios are provided in parentheses.

Table 1 about here

Labour migrants typically are young, male and educated. According to Table 1, age at entry has a negative effect on family reunion for Germany (positive for Denmark) and positive effects on the probability for refugee/asylum status for both countries compared with labour migrants. However, it is only for Germany that the marginal effects are statistically significant. In Germany and in comparison to individuals with a work status, education has a positive marginal effect for family reunion and a negative marginal for the refugee/asylum status, while work experience has a negative effect on family reunion and a positive (but not significant) marginal for refugees/asylum seekers. Similar to Germany, and in comparison to labour migrants, more work experience in Denmark is associated with a higher probability of arriving 
through the channel of family reunion, but refugees/asylum seekers are not different from those arriving as workers. Pre-migration education at home does not play a role at all in Denmark.

Males in both countries are consistently and significantly more present among refugees and asylum seekers, and they are less present in the family reunion category. Only in Denmark does the fact that the father was self-employed predict a significant effect different from the labour migrants, with family reunion being less likely for such migrants. Individuals with Muslim faith exhibit a higher likelihood of family reunion in both countries, and a lower probability of being an asylum seeker or refugee in Denmark. True religious believers with a higher attendance of religious services are less present among refugees and asylum seekers in both countries, but more present in the family reunion category in Denmark. Immigration involving networks is more likely to be a family reunion and less likely to be refugee/asylum status in both countries. There are also strong ethnic differences: Turks in both countries are less present among refugees and asylum seekers, but more likely in the family reunion channel than most other ethnic groups.

These results lead us to conclude that Denmark has very few economic immigrants: this category has a three times higher share in Germany, and indicators of labour market skills play a small role in distinguishing labour migrants from individuals arriving through other channels.

Our second econometric analysis estimates 'Tobit' log earnings regressions using the remuneration from paid-employment or self-employment as the dependent variable. This implies that persons not employed have a value of zero and those with positive earnings have log earnings. Regressors include both family reunion and refugee/asylum status as determinants and measures of factors explaining the change of work participation and income across time after immigration. Those determinants include age, age squared, relative exposure to the host country (years since migration divided by age), relative exposure squared, education in the host country (primary/secondary or Abitur/university leaving no education as the reference category), and vocational training in the host country. We also include education and work experience in the 
home country, the gender status (male) and the ethnicity dummy variables, leaving Turks as the reference group.

Table 2 about here

The constant and all variables were interacted with a self-employment dummy. Hence, Table 2 reports coefficients and marginals for the paid-employment status (columns 1 and 2 for Germany and 5 and 6 for Denmark) and the difference estimates associated with selfemployment status (columns 3 and 4 for Germany and 7 and 8 for Denmark). Columns 3, 4, 7 and 8 provide specific tests whether their effects are different between paid- or self-employed individuals (at the level of the individual variables). Robust t-ratios, estimates of the error variance, the log-likelihood function value and the Pseudo- $\mathrm{R}^{2}$ decomposition measure suggested by Veall and Zimmermann (1994) are also provided. In Denmark, earnings of self-employed migrants are not different from the paid-employed with the exception of Iranian entrepreneurs who earn more other determinants being equal. To the contrary, most of the difference effects are statistically significant for Germany indicating a quite different earnings situation in the two employment categories.

Age and length of time in the host country increase earnings in both Germany and Denmark at a decreasing rate. Education and vocational training in the host country and education and work experience in the home country exhibit a mostly significant positive effect on employee earnings. Also male workers earn more in both countries. In Germany, exYugoslavian, Polish and Iranian workers earn more and Lebanese workers earn less than Turks. In Denmark, we find similar ethnic differences among workers, with the exception of the Iranians whose earnings are not significantly different from the Turks. The self-employed in Germany have a substantially higher base income than the employees. However, their earnings’ advantage decrease with age, country exposure, education, vocational training and work experience in the home country and among males. Only Lebanese have higher self-employment 
earnings than Turks, while the other ethnic entrepreneurs experience a negative ethnicity effect on their income in comparison with the Turks.

Arriving through family reunion or as asylum seekers or refugees affects paidemployment earnings negatively in both Germany and Denmark. However, while the effect is about the same size for both groups in Denmark, the refugee/asylum status is more harmful in Germany than the family reunion status. Individuals arriving with a work status in Germany are more likely to earn less when changing to self-employment than when arriving through another channel. These estimates suggest that there are long-lasting effects of the legal status at entry in country on the earnings potential of immigrants. Hence, a selective immigration policy might be helpful in ensuring the attraction of individuals who will be more successful in the labour market.

\section{Policy Discussion}

This paper provides additional evidence that immigrants with a refugee or asylum seeker status have problems integrating into the labour market of the host country and achieve lower earnings during their stay. Both countries investigated in this study, Germany and Denmark, have very few economic immigrants. Although this category has a three times higher share in Germany than in Denmark, indicators of labour market skills play a small role in distinguishing labour migrants from individuals arriving through other channels in both countries. Ethnic networks foster the arrival of immigrants through the family reunion and the refugee or asylum channels. Migrants who come for the purpose of family reunification fare worse than economic migrants, but earn more than refugees and asylum seekers in Germany, while the effect is of about the same size for both groups in Denmark. Individuals arriving with a work permit in Germany are more likely to earn less when changing to self-employment than when arriving through another channel. These estimates suggest that there are long-lasting effects of the legal status at entry in the country on the earnings potential of migrants. The findings reported in this paper suggest that 
both countries could benefit considerably by executing more pro-active labour market recruitment and integration measures. Economic incentives seem to matter and a more selective immigration policy that generates more active participants in the labour market should be beneficial to the economy.

These findings have important implications for the design of immigration and integration policies. We believe that there is a need for a dual strategy for the efficient allocation of immigration rights that would raise welfare in comparison to current migration policies. Such a strategy needs to addresse the requirements of the labour market and should be designed to select potential migrants with the highest value for the immigration country. We now describe such a strategy. Immigrants should be selected using observable and measurable criteria to choose better-qualified applicants. Successful examples for allocating permanent immigration rights are typically implemented by point systems in several traditional immigration countries. It is known that the average qualification level of immigrants granted permanent residence visas by countries operating under point systems are higher than that of immigrants into countries where immigration is not controlled by economic criteria.

Any economically motivated long-term immigration strategy should make a distinction between skilled labour, investors and business immigrants. Business immigrants and investors create opportunities for employment and income and should therefore be highly welcome. Permanent labour immigrants should be primarily selected by a point system; it should be a tool to select immigrants in accordance to demographic and economic needs. It will be necessary to define minimum requirements including above all a maximum age, minimum qualifications and adequate financial resources for an initial period in the country. A language test should be mandatory and a failure of the test could trigger an obligation of the immigrant to pay a security deposit which would be reimbursed following the successful completion of language tuition in the host country. In the point system, priority should be given to criteria such as age, education, qualifications and work experience or a prior firm job offer. Integrational elements to be 
addressed by the point system include prior stays in Europe, relatives living in Europe, accompanying children and above all language skills. Applicants should be required to achieve a minimum score to be considered for permanent immigration. As immigration is permanent, an appropriate immigration program should be designed based on an "integration contract" relationship between the immigrant and the society of which the immigrant will be a member. A European-wide quota on permanent migrants would allow fixing the number of permanent visas at the political level.

The immigration of investors and business people should be approved directly outside the point system. Investor immigration should exclusively be governed by the sum invested. For business people, on the other hand, who invest in a new or an existing business, the development of the business should be reviewed regularly. Student immigration should be facilitated to create early ties of highly qualified young persons in Europe. The selection of undergraduates should be left entirely to universities. Strict local native language requirements are not so important for academics, since academic courses can be taught in other languages. After graduation, student immigrants should have the right to obtain permanent residence if they have a concrete job offer. Immigrants taking up firm traineeships or apprenticeships should also be allowed to enter the country under the student program.

Urgent needs for short-term skilled labour should be accommodated by establishing a non-bureaucratic system for temporary immigration. Unfortunately, it is very difficult if not impossible for a public administrator or an outside observer to identify the real short-term needs of the business community. Hence, an auction system operating among interested companies for the allocation of immigration certificates would appear to be the best choice to satisfy temporary immigration needs. These certificates would entitle the company to recruit an immigrant on the world market for a job for a defined period of time. Such an auction system translates relative labour market shortages into relative bid prices. Existing shortages would become transparent and excess demand would show where further policy response is necessary. Since companies 
would have to pay for the right to hire a worker, a share of the immigration gains would be given to the public coffers. A European-wide quota on temporary migrants would allow fixing the number of temporary visas at the political level.

An auction system is superior to alternatives such as a fee system where companies have to pay an amount which has been fixed according to political rules mainly as it matches supply and demand more efficiently. Companies will only be willing to purchase at an auction if they are unable to satisfy their demand on the regular local labour market. The objective of the auction can be underscored by a minimum bid requirement. There is no need to verify formally the non-availability of native labour. The certificates should be limited to a period of three years, and could be potentially renewable for the same person. Temporary immigrants should have the right to be accompanied by their family members, and spouses should be entitled to a work permit. During their employment under this programme, temporary immigrants should have the right to apply for permanent immigration under the point system. Such an arrangement would create an appropriate link between the temporary and the permanent immigration systems. 


\section{References}

Bauer, T., B. Dietz, K. F. Zimmermann and E. Zwintz (2005), 'German Migration: Development, Assimilation, and Labour Market Effects,' in: K. F. Zimmermann (ed.), European Migration: What Do We Know?, Oxford, Oxford University Press, pp. 197-261.

Bauer, T., M. Lofstrom and K. F. Zimmermann (2000), 'Immigration Policy, Assimilation of Immigrants and Natives' Sentiments Towards Immigrants: Evidence from 12 OECD Countries', Swedish Economic Policy Review, 7, pp. 11-53.

Bauer, T. and K. F. Zimmermann (1997), 'Integrating the East: The Labor Market Effects of Immigration,' in: S.W. Black (ed.), Europe's Economy Looks East - Implications for Germany and the European Union, Cambridge, Cambridge University Press, pp. 269306.

Bauer, T. and N.-K. Nielsen (2004), 'Data Description,' in: T. Tranaes and K. F. Zimmermann (ed.), Migrants, Work, and the Welfare State, Odense, University Press of Southern Denmark, pp. 405-427.

Boeri, T., G. Hanson and B. McCormick (2002), Immigration Policy and the Welfare System, Oxford, Oxford University Press.

Borjas, G. J. (1994), 'The Economics of Immigration,' Journal of Economic Literature, 32, pp. 1667-1717.

Commission of the European Communities (2005), Green Paper on an EU Approach to Managing Economic Migration, Brussels.

Constant, A. and M. L. Schultz-Nielsen (2004a), 'Labor Force Participation and Unemployment: Incentives and Preferences,' in: T. Tranaes and K. F. Zimmermann Migrants, Work, and the Welfare State, Odense, University Press of Southern Denmark, pp. 147-186.

Constant, A. and M. L. Schultz-Nielsen (2004b), 'Immigrant Selection and Earnings,' in: T. Tranaes and K. F. Zimmermann Migrants, Work, and the Welfare State, Odense, University Press of Southern Denmark, pp. 147-186.

Constant, A. and K. F. Zimmermann (2005), 'The Making of Entrepreneurs in Germany: Are Native Men and Immigrants Alike?', forthcoming: Small Business Economics

European Communities (2003), Employment in Europe 2003. Recent Trends and Prospects, Luxembourg, Office for Official Publications of the European Communities.

Petersen, P. J. (2005), 'Migration in a Scandinavian Welfare State: The Recent Danish Experience,' in: K. F. Zimmermann (ed.), European Migration: What Do We Know?, Oxford, Oxford University Press, pp. 59-112.

Sapir Report (2005), André Sapir, Philippe Aghion, Giuseppe Bertola, Martin Hellwig, Jean Pisani-Ferry, Dariusz Rosati, José Vinals, Helen Wallace. An Agenda for a Growing Europe. Oxford: Oxford University Press.

Schultz-Nielsen, M. L. and A. Constant (2004), 'Employment Trends for Immigrants and Natives,' in: T. Tranaes and K. F. Zimmermann Migrants, Work, and the Welfare State, Odense, University Press of Southern Denmark, pp. 119-146.

Tranaes, T. and K. F. Zimmermann (2004a), Migrants, Work, and the Welfare State, Odense, University Press of Southern Denmark.

Tranaes, T. and K. F. Zimmermann (2004b), 'Migrants, Work, and the Welfare State: An Introduction,' in: T. Tranaes and K. F. Zimmermann Migrants, Work, and the Welfare State, Odense, University Press of Southern Denmark, pp. 15-29.

Veall, M. R. and K. F. Zimmermann (1994), 'Goodness of Fit Measures in the Tobit Model', Oxford Bulletin of Economics and Statistics, vol. 56, pp. 485-496.

Venturini, A. (2004), Post-War Migration in Southern Europe. An Economic Approach, Cambridge, Cambridge University Press. 
Zimmermann, K. F. (1995), 'European Migration: Push and Pull', Proceedings of the World Bank Annual Conference on Development Economics 1994, World Bank Economic Review, and World Bank Research Observer, pp. 313-342.

Zimmermann, K. F. (2005) (ed.), European Migration: What Do We Know?, Oxford, Oxford University Press. 


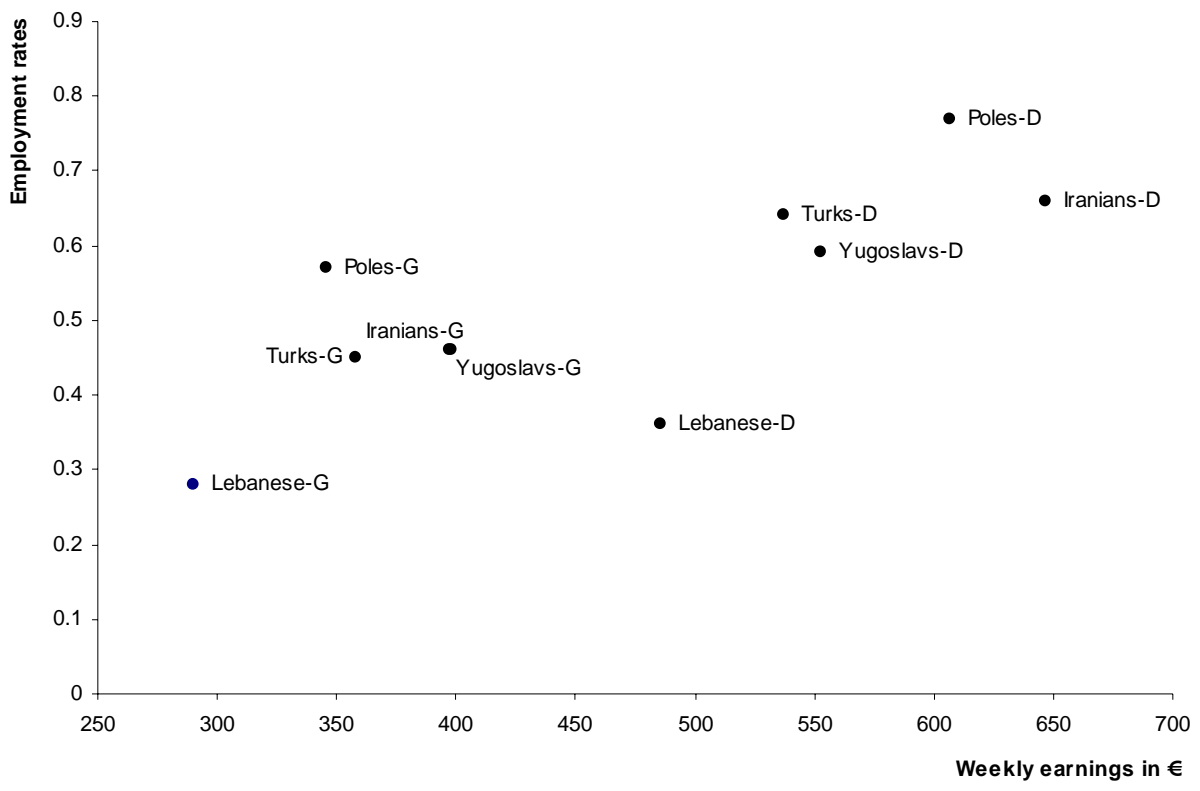

Figure 1: Employment rates and weekly earnings by ethnicity; Germany (G) and Denmark (D)

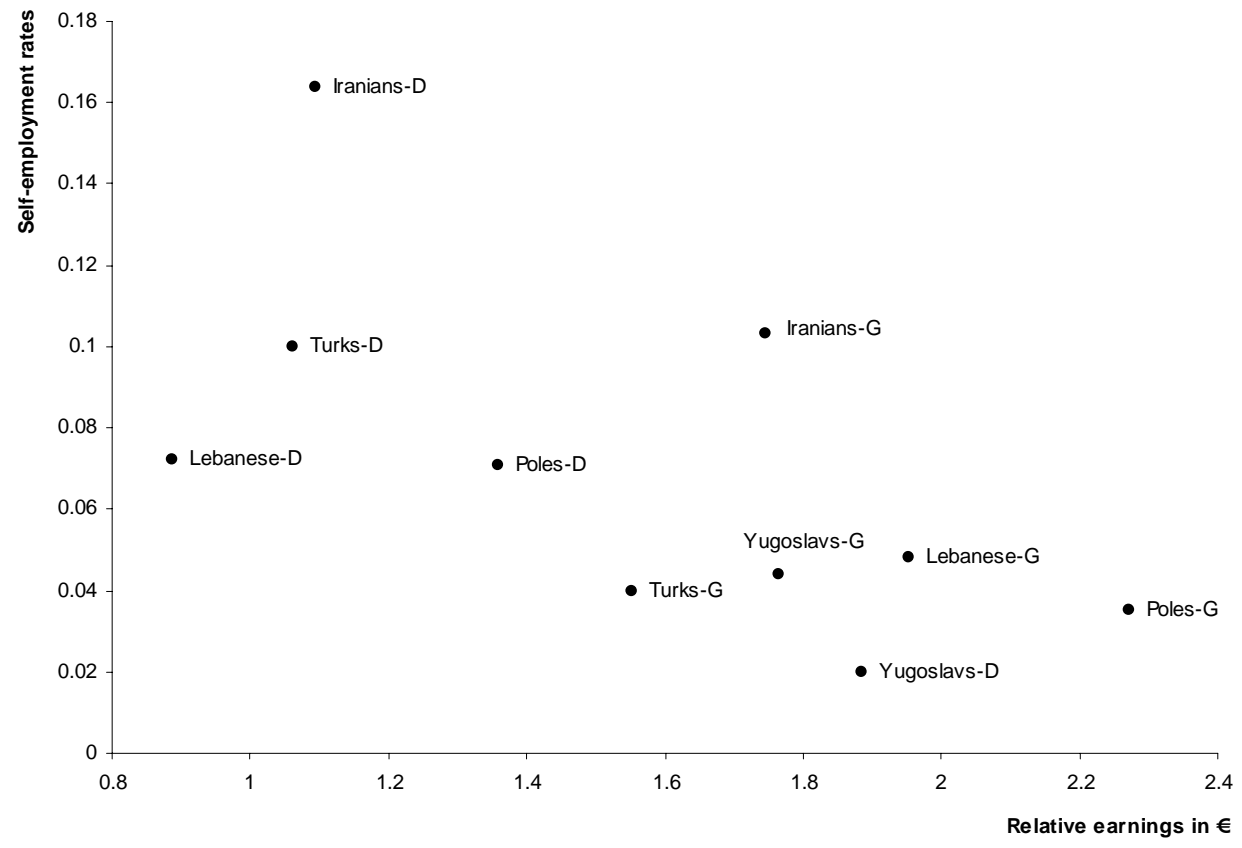

Figure 2: Self-employment rates and relative weekly earnings by ethnicity; Germany (G) and Denmark (D) 
Table 1. Multinomial logit analysis on status at entry

\begin{tabular}{|c|c|c|c|c|c|c|c|c|}
\hline & \multicolumn{4}{|c|}{ Germany } & \multicolumn{4}{|c|}{ Denmark } \\
\hline & \multicolumn{2}{|c|}{ Family Reunion } & \multicolumn{2}{|c|}{ Refugee/Asylum } & \multicolumn{2}{|c|}{ Family Reunion } & \multicolumn{2}{|c|}{ Refugee/Asylum } \\
\hline & $\begin{array}{c}\text { Coefficient } \\
\text { (t-ratio) }\end{array}$ & $\begin{array}{c}\text { Marginals } \\
\text { (t-ratio) }\end{array}$ & $\begin{array}{c}\text { Coefficient } \\
\text { (t-ratio) }\end{array}$ & $\begin{array}{c}\text { Marginals } \\
\text { (t-ratio) }\end{array}$ & $\begin{array}{c}\text { Coefficient } \\
\text { (t-ratio) }\end{array}$ & $\begin{array}{c}\text { Marginals } \\
\text { (t-ratio) }\end{array}$ & $\begin{array}{c}\text { Coefficient } \\
\text { (t-ratio) }\end{array}$ & $\begin{array}{c}\text { Marginals } \\
\text { (t-ratio) }\end{array}$ \\
\hline Constant & $\begin{array}{c}0.926^{* *} \\
(3.54)\end{array}$ & $\begin{array}{c}0.356^{* *} \\
(6.83)\end{array}$ & $\begin{array}{c}-0.727^{* *} \\
(-2.61)\end{array}$ & $\begin{array}{c}-0.336^{* *} \\
(-6.50)\end{array}$ & $\begin{array}{l}0.570 \\
(0.89)\end{array}$ & $\begin{array}{c}0.566^{* *} \\
(4.30)\end{array}$ & $\begin{array}{c}-1.921^{* *} \\
(-2.46)\end{array}$ & $\begin{array}{c}-0.586^{* *} \\
(-4.35)\end{array}$ \\
\hline Age at entry & $\begin{array}{c}-0.016^{* *} \\
(-2.40)\end{array}$ & $\begin{array}{c}-0.008 * * \\
(-5.97)\end{array}$ & $\begin{array}{c}0.021^{* *} \\
(3.30)\end{array}$ & $\begin{array}{c}0.008 * * \\
(6.38)\end{array}$ & $\begin{array}{l}0.031 * \\
(1.71)\end{array}$ & $\begin{array}{l}-0.002 \\
(-0.78)\end{array}$ & $\begin{array}{c}0.044^{* *} \\
(2.47)\end{array}$ & $\begin{array}{l}0.004 \\
(1.46)\end{array}$ \\
\hline $\begin{array}{l}\text { Education in the home } \\
\text { country }\end{array}$ & $\begin{array}{l}-0.310^{*} \\
(-1.84)\end{array}$ & $\begin{array}{l}0.056^{*} \\
(1.93)\end{array}$ & $\begin{array}{c}-0.754 * * \\
(-4.33)\end{array}$ & $\begin{array}{c}-0.126^{* *} \\
(-4.35)\end{array}$ & $\begin{array}{l}0.709 * \\
(1.68)\end{array}$ & $\begin{array}{l}0.096 \\
(1.23)\end{array}$ & $\begin{array}{l}0.357 \\
(0.78)\end{array}$ & $\begin{array}{l}-0.071 \\
(-0.91)\end{array}$ \\
\hline $\begin{array}{l}\text { Work experience in the } \\
\text { home country }\end{array}$ & $\begin{array}{c}-0.341^{* *} \\
(-2.55)\end{array}$ & $\begin{array}{l}-0.048^{*} \\
(-1.95)\end{array}$ & $\begin{array}{l}-0.205 \\
(-1.47)\end{array}$ & $\begin{array}{l}0.011 \\
(0.45)\end{array}$ & $\begin{array}{l}-0.623^{*} \\
(-1.80)\end{array}$ & $\begin{array}{l}-0.094^{*} \\
(-2.03)\end{array}$ & $\begin{array}{l}-0.269 \\
(-0.73)\end{array}$ & $\begin{array}{l}0.073 \\
(1.56)\end{array}$ \\
\hline Male & $\begin{array}{c}-1.417 * * \\
(-12.75)\end{array}$ & $\begin{array}{c}-0.299 * * \\
(-14.21)\end{array}$ & $\begin{array}{c}-0.292^{* *} \\
(-2.52)\end{array}$ & $\begin{array}{c}0.179 * * \\
(8.53)\end{array}$ & $\begin{array}{c}-1.414^{* *} \\
(-4.79)\end{array}$ & $\begin{array}{c}-0.385 * * \\
(-9.19)\end{array}$ & $\begin{array}{l}0.162 \\
(0.54)\end{array}$ & $\begin{array}{c}0.352^{* *} \\
(8.49)\end{array}$ \\
\hline Father self-employed & $\begin{array}{c}-0.431^{* *} \\
(-3.45)\end{array}$ & $\begin{array}{l}-0.022 \\
(-0.89)\end{array}$ & $\begin{array}{c}-0.480 * * \\
(-3.72)\end{array}$ & $\begin{array}{l}-0.039 \\
(-1.56)\end{array}$ & $\begin{array}{c}-1.219 * * \\
(-4.21)\end{array}$ & $\begin{array}{c}-0.119 * * \\
(-2.54)\end{array}$ & $\begin{array}{c}-0.821^{* *} \\
(-2.73)\end{array}$ & $\begin{array}{l}0.073 \\
(1.58)\end{array}$ \\
\hline Muslim faith & $\begin{array}{c}0.813^{* *} \\
(5.71)\end{array}$ & $\begin{array}{c}0.072^{* *} \\
(2.52)\end{array}$ & $\begin{array}{c}0.734^{* *} \\
(5.14)\end{array}$ & $\begin{array}{l}0.033 \\
(1.18)\end{array}$ & $\begin{array}{c}1.025^{* *} \\
(2.67)\end{array}$ & $\begin{array}{c}0.131^{* *} \\
(2.34)\end{array}$ & $\begin{array}{l}0.551 \\
(1.54)\end{array}$ & $\begin{array}{c}-0.095 * \\
(-1.79)\end{array}$ \\
\hline $\begin{array}{l}\text { Attend religious services } \\
\text { often }\end{array}$ & $\begin{array}{l}-0.249^{*} \\
(-2.16)\end{array}$ & $\begin{array}{l}0.005 \\
(0.22)\end{array}$ & $\begin{array}{c}-0.378 * * \\
(-3.27)\end{array}$ & $\begin{array}{l}-0.046^{*} \\
(-2.27)\end{array}$ & $\begin{array}{l}-0.273 \\
(-0.98)\end{array}$ & $\begin{array}{c}0.113^{* *} \\
(2.65)\end{array}$ & $\begin{array}{c}-0.817^{* *} \\
(-2.83)\end{array}$ & $\begin{array}{c}-0.135^{* *} \\
(-3.16)\end{array}$ \\
\hline Used network migration & $\begin{array}{l}1.712 * * \\
(14.51)\end{array}$ & $\begin{array}{l}0.383^{* *} \\
(15.97)\end{array}$ & $\begin{array}{l}0.226^{*} \\
(2.05)\end{array}$ & $\begin{array}{l}-0.246 * * \\
(-11.24)\end{array}$ & $\begin{array}{c}1.306^{* *} \\
(4.03)\end{array}$ & $\begin{array}{c}0.430 * * \\
(9.72)\end{array}$ & $\begin{array}{l}-0.485 \\
(-1.49)\end{array}$ & $\begin{array}{c}-0.405^{* *} \\
(-9.15)\end{array}$ \\
\hline Yugoslavian & $\begin{array}{c}-0.458 * * \\
(-2.89)\end{array}$ & $\begin{array}{l}-0.403^{* *} \\
(-11.49)\end{array}$ & $\begin{array}{l}1.650^{* *} \\
(8.70)\end{array}$ & $\begin{array}{l}0.474 * * \\
(12.76)\end{array}$ & $\begin{array}{l}-0.908 * \\
(-2.23)\end{array}$ & $\begin{array}{c}-0.831^{* *} \\
(-9.43)\end{array}$ & $\begin{array}{c}2.744^{* *} \\
(5.58)\end{array}$ & $\begin{array}{c}0.858 * * \\
(9.75)\end{array}$ \\
\hline Polish & $\begin{array}{c}0.732 * * \\
(3.79)\end{array}$ & $\begin{array}{l}0.056 \\
(1.23)\end{array}$ & $\begin{array}{c}0.714^{* *} \\
(2.90)\end{array}$ & $\begin{array}{l}0.042 \\
(0.83)\end{array}$ & $\begin{array}{c}1.573^{* *} \\
(2.85)\end{array}$ & $\begin{array}{c}-0.313 * * \\
(-2.99)\end{array}$ & $\begin{array}{c}3.172 * * \\
(4.99)\end{array}$ & $\begin{array}{c}0.412^{* *} \\
(3.87)\end{array}$ \\
\hline Iranian & $\begin{array}{l}0.310 \\
(1.51)\end{array}$ & $\begin{array}{c}-0.468 * * \\
(-13.33)\end{array}$ & $\begin{array}{l}3.105^{* *} \\
(14.12)\end{array}$ & $\begin{array}{c}0.686^{* *} \\
(19.07)\end{array}$ & $\begin{array}{l}2.188^{*} \\
(1.98)\end{array}$ & $\begin{array}{l}-0.862 * * \\
(-10.44)\end{array}$ & $\begin{array}{c}6.341^{* *} \\
(5.59)\end{array}$ & $\begin{array}{l}1.036 * * \\
(12.03)\end{array}$ \\
\hline Lebanese & $\begin{array}{l}0.310 \\
(1.45)\end{array}$ & $\begin{array}{c}-0.548 * * \\
(-16.67)\end{array}$ & $\begin{array}{l}3.559 * * \\
(16.39)\end{array}$ & $\begin{array}{l}0.795^{* *} \\
(23.74)\end{array}$ & $\begin{array}{l}0.939 * \\
(1.67)\end{array}$ & $\begin{array}{c}-0.847 * * \\
(-10.78)\end{array}$ & $\begin{array}{c}4.876^{* *} \\
(7.53)\end{array}$ & $\begin{array}{c}0.961^{* *} \\
(12.04)\end{array}$ \\
\hline Log-likelihood function & \multicolumn{4}{|c|}{$-2,843.897$} & \multicolumn{4}{|c|}{-735.385} \\
\hline Chi-squared & \multirow{2}{*}{\multicolumn{2}{|c|}{1,647}} & 94 & & & & & \\
\hline $\begin{array}{l}\text { Observations } \\
\text { Total observations }\end{array}$ & & & \multicolumn{2}{|c|}{1,572} & \multicolumn{2}{|c|}{682} & \multicolumn{2}{|c|}{652} \\
\hline
\end{tabular}

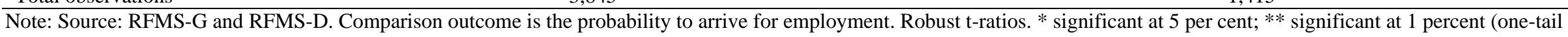
test). Marginal effects are computed at the means of the regressors. 
Table 2. Tobit log earnings regressions

\begin{tabular}{|c|c|c|c|c|c|c|c|c|}
\hline & \multicolumn{4}{|c|}{ Germany } & \multicolumn{4}{|c|}{ Denmark } \\
\hline & \multicolumn{2}{|c|}{ Paid-employed } & \multicolumn{2}{|c|}{$\begin{array}{c}\text { Self-employed } \\
\text { Difference }\end{array}$} & \multicolumn{2}{|c|}{ Paid-employed } & \multicolumn{2}{|c|}{$\begin{array}{c}\text { Self-employed } \\
\text { Difference }\end{array}$} \\
\hline & $\begin{array}{l}\text { Coefficient } \\
\text { (t-ratio) }\end{array}$ & $\begin{array}{l}\text { Marginals } \\
\text { (t-ratio) }\end{array}$ & $\begin{array}{l}\text { Coefficient } \\
\text { (t-ratio) }\end{array}$ & $\begin{array}{c}\text { Marginals } \\
\text { (t-ratio) }\end{array}$ & $\begin{array}{l}\text { Coefficient } \\
\text { (t-ratio) }\end{array}$ & $\begin{array}{l}\text { Marginals } \\
\text { (t-ratio) }\end{array}$ & $\begin{array}{l}\text { Coefficient } \\
\text { (t-ratio) }\end{array}$ & $\begin{array}{l}\text { Marginals } \\
\text { (t-ratio) }\end{array}$ \\
\hline Constant & $\begin{array}{c}-7.750 * * \\
(-3.26)\end{array}$ & $\begin{array}{c}-4.348 * * \\
(-4.91)\end{array}$ & $\begin{array}{c}12.195 * * \\
(4.86)\end{array}$ & $\begin{array}{c}6.842 * * \\
(7.82)\end{array}$ & $\begin{array}{l}-2.156 \\
(-0.97)\end{array}$ & $\begin{array}{l}-1.614 \\
(-1.03)\end{array}$ & $\begin{array}{l}1.584 \\
(0.29)\end{array}$ & $\begin{array}{l}1.186 \\
(0.29)\end{array}$ \\
\hline Age & $\begin{array}{c}0.268^{* *} \\
(3.54)\end{array}$ & $\begin{array}{c}0.150^{* *} \\
(4.07)\end{array}$ & $\begin{array}{c}-0.226 * * \\
(-2.70)\end{array}$ & $\begin{array}{c}-0.127 * * \\
(-3.01)\end{array}$ & $\begin{array}{l}0.195^{*} \\
(1.95)\end{array}$ & $\begin{array}{l}0.146^{*} \\
(1.98)\end{array}$ & $\begin{array}{l}-0.351 \\
(-1.34)\end{array}$ & $\begin{array}{l}-0.263 \\
(-1.36)\end{array}$ \\
\hline Age squared & $\begin{array}{c}-0.004 * * \\
(-3.92)\end{array}$ & $\begin{array}{c}-0.002 * * \\
(-4.83)\end{array}$ & $\begin{array}{c}0.003^{* *} \\
(3.24)\end{array}$ & $\begin{array}{c}0.002^{* *} \\
(3.86)\end{array}$ & $\begin{array}{c}-0.003 * * \\
(-2.46)\end{array}$ & $\begin{array}{c}-0.002 * * \\
(-2.57)\end{array}$ & $\begin{array}{l}0.006^{*} \\
(1.75)\end{array}$ & $\begin{array}{l}0.004^{*} \\
(1.80)\end{array}$ \\
\hline $\begin{array}{l}\text { Relative exposure to the host } \\
\text { country }\end{array}$ & $\begin{array}{c}10.477^{* *} \\
(4.38)\end{array}$ & $\begin{array}{c}5.879 * * \\
(6.38)\end{array}$ & $\begin{array}{c}-8.092 * * \\
(-2.76)\end{array}$ & $\begin{array}{c}-4.540 * * \\
(-3.34)\end{array}$ & $\begin{array}{c}8.972 * * \\
(2.84)\end{array}$ & $\begin{array}{c}6.717 * * \\
(3.23)\end{array}$ & $\begin{array}{l}10.615 \\
(1.06)\end{array}$ & $\begin{array}{l}7.948 \\
(1.07)\end{array}$ \\
\hline $\begin{array}{l}\text { Relative exposure to the host } \\
\text { country squared }\end{array}$ & $\begin{array}{c}-6.675^{* *} \\
(-3.12)\end{array}$ & $\begin{array}{c}-3.745^{* *} \\
(-3.57)\end{array}$ & $\begin{array}{l}4.461^{*} \\
(1.65)\end{array}$ & $\begin{array}{c}2.503^{*} \\
(1.76)\end{array}$ & $\begin{array}{c}-6.908 * * \\
(-2.35)\end{array}$ & $\begin{array}{c}-5.172^{* *} \\
(-2.56)\end{array}$ & $\begin{array}{c}-11.607 \\
(-1.07)\end{array}$ & $\begin{array}{l}-8.690 \\
(-1.08)\end{array}$ \\
\hline $\begin{array}{l}\text { Primary/secondary education } \\
\text { in the host country }\end{array}$ & $\begin{array}{c}0.743^{*} \\
(2.05)\end{array}$ & $\begin{array}{l}0.417^{*} \\
(2.16)\end{array}$ & $\begin{array}{c}-1.007 * * \\
(-2.53)\end{array}$ & $\begin{array}{c}-0.565^{* *} \\
(-2.63)\end{array}$ & $\begin{array}{l}0.515 \\
(1.29)\end{array}$ & $\begin{array}{l}0.386 \\
(1.31)\end{array}$ & $\begin{array}{l}-0.918 \\
(-0.87)\end{array}$ & $\begin{array}{l}-0.687 \\
(-0.87)\end{array}$ \\
\hline $\begin{array}{l}\text { Abitur/university in the host } \\
\text { country }\end{array}$ & $\begin{array}{l}1.056^{*} \\
(2.17)\end{array}$ & $\begin{array}{l}0.592^{*} \\
(2.27)\end{array}$ & $\begin{array}{c}-1.051^{*} \\
(-2.04)\end{array}$ & $\begin{array}{c}-0.590^{*} \\
(-2.12)\end{array}$ & $\begin{array}{c}1.115^{* *} \\
(2.72)\end{array}$ & $\begin{array}{c}0.835^{* *} \\
(2.87)\end{array}$ & $\begin{array}{l}-0.274 \\
(-0.35)\end{array}$ & $\begin{array}{l}-0.205 \\
(-0.35)\end{array}$ \\
\hline $\begin{array}{l}\text { Vocational training in the host } \\
\text { country }\end{array}$ & $\begin{array}{c}1.478^{* *} \\
(4.60)\end{array}$ & $\begin{array}{c}0.830^{* *} \\
(5.53)\end{array}$ & $\begin{array}{c}-1.446 * * \\
(-3.78)\end{array}$ & $\begin{array}{c}-0.811^{* *} \\
(-4.28)\end{array}$ & $\begin{array}{c}1.512^{* *} \\
(3.94)\end{array}$ & $\begin{array}{c}1.132 * * \\
(4.72)\end{array}$ & $\begin{array}{l}-0.280 \\
(-0.37)\end{array}$ & $\begin{array}{l}-0.210 \\
(-0.37)\end{array}$ \\
\hline Education in the home country & $\begin{array}{c}1.287^{* *} \\
(3.38)\end{array}$ & $\begin{array}{c}0.722^{* *} \\
(4.28)\end{array}$ & $\begin{array}{c}-1.314 * * \\
(-3.13)\end{array}$ & $\begin{array}{c}-0.737 * * \\
(-3.78)\end{array}$ & $\begin{array}{l}-0.069 \\
(-0.14)\end{array}$ & $\begin{array}{l}-0.051 \\
(-0.14)\end{array}$ & $\begin{array}{l}2.931 \\
(1.24)\end{array}$ & $\begin{array}{l}2.194 \\
(1.27)\end{array}$ \\
\hline $\begin{array}{l}\text { Work experience in home } \\
\text { country }\end{array}$ & $\begin{array}{l}0.604^{*} \\
(2.26)\end{array}$ & $\begin{array}{c}0.339 * * \\
(2.54)\end{array}$ & $\begin{array}{c}-0.677^{*} \\
(-2.08)\end{array}$ & $\begin{array}{l}-0.380^{*} \\
(-2.26)\end{array}$ & $\begin{array}{l}-0.060 \\
(-0.18)\end{array}$ & $\begin{array}{l}-0.045 \\
(-0.18)\end{array}$ & $\begin{array}{l}-0.664 \\
(-0.87)\end{array}$ & $\begin{array}{l}-0.497 \\
(-0.87)\end{array}$ \\
\hline Male & $\begin{array}{c}2.746^{* *} \\
(6.03)\end{array}$ & $\begin{array}{l}1.541^{* *} \\
(14.06)\end{array}$ & $\begin{array}{c}-2.322 * * \\
(-4.69)\end{array}$ & $\begin{array}{c}-1.303^{* *} \\
(-8.09)\end{array}$ & $\begin{array}{c}1.970^{* *} \\
(4.82)\end{array}$ & $\begin{array}{c}1.475^{* *} \\
(6.95)\end{array}$ & $\begin{array}{l}-1.490 \\
(-1.44)\end{array}$ & $\begin{array}{l}-1.115 \\
(-1.49)\end{array}$ \\
\hline $\begin{array}{l}\text { Arrived through family } \\
\text { reunion }\end{array}$ & $\begin{array}{c}-1.520 * * \\
(-4.59)\end{array}$ & $\begin{array}{c}-0.853 * * \\
(-5.91)\end{array}$ & $\begin{array}{c}1.735^{* *} \\
(4.61)\end{array}$ & $\begin{array}{c}0.974 * * \\
(5.50)\end{array}$ & $\begin{array}{l}-1.306^{*} \\
(-2.22)\end{array}$ & $\begin{array}{c}-0.978 * * \\
(-2.33)\end{array}$ & $\begin{array}{l}1.012 \\
(0.57)\end{array}$ & $\begin{array}{l}0.757 \\
(0.57)\end{array}$ \\
\hline Arrived as refugee/asylum & $\begin{array}{c}-2.415^{* *} \\
(-5.32)\end{array}$ & $\begin{array}{c}-1.355^{* *} \\
(-8.24)\end{array}$ & $\begin{array}{c}2.085^{* *} \\
(4.39)\end{array}$ & $\begin{array}{c}1.170^{* *} \\
(6.35)\end{array}$ & $\begin{array}{c}-1.463 * * \\
(-2.39)\end{array}$ & $\begin{array}{c}-1.095^{* *} \\
(-2.54)\end{array}$ & $\begin{array}{l}-0.069 \\
(-0.03)\end{array}$ & $\begin{array}{l}-0.052 \\
(-0.03)\end{array}$ \\
\hline Yugoslavian & $\begin{array}{c}0.858^{* *} \\
(2.70)\end{array}$ & $\begin{array}{c}0.481^{* *} \\
(2.97)\end{array}$ & $\begin{array}{c}-0.616^{*} \\
(-1.71)\end{array}$ & $\begin{array}{c}-0.346^{*} \\
(-1.82)\end{array}$ & $\begin{array}{l}1.063^{*} \\
(2.17)\end{array}$ & $\begin{array}{l}0.796^{*} \\
(2.28)\end{array}$ & $\begin{array}{l}-2.839 \\
(-1.36)\end{array}$ & $\begin{array}{l}-2.125 \\
(-1.41)\end{array}$ \\
\hline Polish & $\begin{array}{c}2.254^{* *} \\
(4.94)\end{array}$ & $\begin{array}{l}1.264^{* *} \\
(8.17)\end{array}$ & $\begin{array}{c}-2.022 * * \\
(-3.83)\end{array}$ & $\begin{array}{c}-1.134 * * \\
(-5.22)\end{array}$ & $\begin{array}{c}2.359 * * \\
(4.52)\end{array}$ & $\begin{array}{c}1.767 * * \\
(5.89)\end{array}$ & $\begin{array}{l}-0.965 \\
(-0.67)\end{array}$ & $\begin{array}{l}-0.723 \\
(-0.67)\end{array}$ \\
\hline Iranian & $\begin{array}{l}0.858 * * \\
(2.38)\end{array}$ & $\begin{array}{c}0.482^{* *} \\
(2.58)\end{array}$ & $\begin{array}{l}-0.537 \\
(-1.39)\end{array}$ & $\begin{array}{l}-0.301 \\
(-1.47)\end{array}$ & $\begin{array}{l}-0.492 \\
(-0.97)\end{array}$ & $\begin{array}{l}-0.369 \\
(-0.98)\end{array}$ & $\begin{array}{c}3.095^{* *} \\
(2.38)\end{array}$ & $\begin{array}{c}2.317^{* *} \\
(2.48)\end{array}$ \\
\hline Lebanese & $\begin{array}{c}-1.954 * * \\
(-3.98)\end{array}$ & $\begin{array}{c}-1.097 * * \\
(-5.71)\end{array}$ & $\begin{array}{c}2.052 * * \\
(3.92)\end{array}$ & $\begin{array}{c}1.151^{* *} \\
(5.34)\end{array}$ & $\begin{array}{c}-3.041 * * \\
(-4.01)\end{array}$ & $\begin{array}{c}-2.277^{* *} \\
(-5.56)\end{array}$ & $\begin{array}{l}1.169 \\
(0.59)\end{array}$ & $\begin{array}{l}0.875 \\
(0.59)\end{array}$ \\
\hline
\end{tabular}


Table 2 - continued. Tobit log earnings regressions

\begin{tabular}{lcc}
\hline Sigma & $4.472^{* *}$ & $4.157^{* *}$ \\
& $(3.36)$ & $(2.93)$ \\
Log-likelihood function value & -6085.87 & -2948.90 \\
Pseudo- $R^{2}$ decomposition & 0.237 & 0.125 \\
Observations & 3,489 & 1,415
\end{tabular}

Note: Source: RFMS-G and RFMS-D. Robust t-ratios. * significant at 5 per cent; ** significant at 1 percent (one-tail test). Marginal effects are computed at the means of the regressors. Pseudo-R² decomposition: Veall and Zimmermann (1994). 